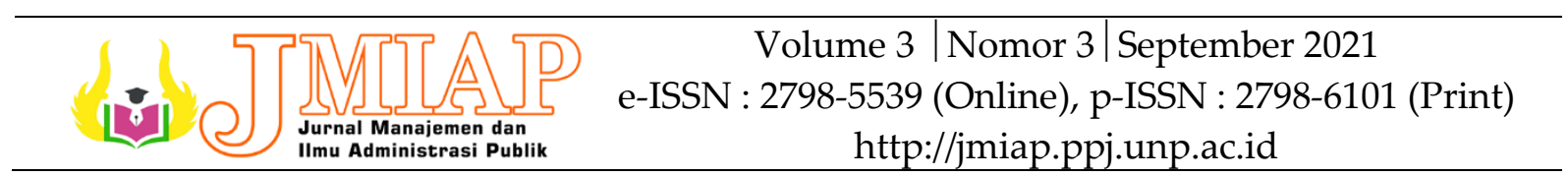

\title{
PENGELOLAAN DANA DESA UNTUK PEMBERDAYAAN MASYARAKAT DESA MULYA SUBUR KECAMATAN PANGKALAN LESUNG KABUPATEN PELALAWAN
}

\author{
Yunita Dewi Rahmawat ${ }^{1(a)}$, Ratna Dewi ${ }^{2(b)}$, Ainun Mardiah ${ }^{2(b)}$ \\ ${ }^{1,2}$ Jurusan Administrasi Negara, Universitas Islam Negeri Sultan Syarif Kasim Riau \\ ${ }^{3}$ Jurusan Manajemen, Universitas Islam Negeri Sultan Syarif Kasim Riau \\ a)yunitadewirahmawati374@gmail.com, ${ }^{b}$ ratna.dewi@uin-suska.ac.id, \\ c)ainun.mardiah@uin-suska.ac.id
}

\begin{tabular}{l}
\multicolumn{1}{c}{\begin{tabular}{c}
\multicolumn{1}{c}{ INFORMASI } \\
ARTIKEL
\end{tabular}} \\
\hline Article History: \\
Dikirim: \\
23-08-2021 \\
Selesai Revisi: \\
15-09-2021 \\
Diterbitkan Online: \\
30-09-2021 \\
\hline
\end{tabular}

\section{Kata Kunci:}

Asas, Pengelolaan, Dana Desa, Pemberdayaan Masyarakat

Keywords:

Principles, Management, Village Funds, Community Empowerment

Corresponding Author: ainun.mardiah@uin-suska.ac.id

DOI:

https://doi.org/10.24036/jmiap.v3i3.315
Tujuan penelitian menganalisa pengelolaan Dana Desa untuk pemberdayaan masyarakat di Desa Mulya Subur Kecamatan Pangkalan Lesung Kabupaten Pelalawan, dengan penerapan asas pengelolaan keuangan Desa. Dalam penelitian ini indikator yang digunakan yakni asas pengelolaan keuangan Desa dalam Permendagri No. 113 tahun 2015 tentang Pengelolaan Keuangan Desa berupa transparan, akuntabel, partisipatif, serta tertib dan disiplin anggaran. Jenis penelitian ini adalah kualitatif dengan sumber data yang digunakan berupa data primer dan data sekunder. Adapun pengumpulan data dilakukan melalui observasi, wawancara, dokumentasi dengan teknik analisis data melalui reduksi data, penyajian data, dan menarik kesimpulan. Hasil peneltian menunjukkan bahwa pengelolaan Dana Desa Mulya Subur belum menerapkan asas pengelolaan Dana Desa secara maksimal. Hal ini dikarenakan pada penerapan asas partisipatif masih terkendala dengan kurangnya dalam membuka ruang bagi peran serta masyarakat. Selain itu, partisipasi dari masyarakat masih bersifat pasif. Dalam pengelolaan Dana Desa juga masih memfokuskan pada kegiatan pembangunan fisik.

ABSTRACT
The purpose of this study was to analyze the management of Village Funds
for community empowerment in Mulya Subur Village, Pangkalan Lesung
District, Pelalawan Regency with the application of village financial
management. In this study, the indicators used are village financial
management in Permendagri Number 113 of 2015 concerning Village
Financial Management in the form of transparency, accountability,
participation, and budget discipline and discipline. This type of research is
qualitative with the data sources used in the form of primary data and
secondary data. Data was collected through observation, interviews,
documentation with data analysis techniques through data reduction, data
presentation, and drawing conclusions. The results of the study indicate that
the management of the Mulya Subur Village Fund has not been carried out
optimally as well as the management of the Village Fund. This is because
the participatory implementation is still constrained by the lack of
community participation in opening up space for participation. In addition,
community participation is still passive. In the management of the Village
Fund, it is also still focused on physical development activities

The purpose of this study was to analyze the management of Village Funds for community empowerment in Mulya Subur Village, Pangkalan Lesung District, Pelalawan Regency with the application of village financial management. In this study, the indicators used are village financial management in Permendagri Number 113 of 2015 concerning Village Financial Management in the form of transparency, accountability, participation, and budget discipline and discipline. This type of research is qualitative with the data sources used in the form of primary data and secondary data. Data was collected through observation, interviews, documentation with data analysis techniques through data reduction, data the management of the Mulya Subur Village Fund has not been carried out optimally as well as the management of the Village Fund. This is because the participatory implementation is still constrained by the lack of community participation in opening up space for participation. In addition, community participation is still passive. In the management of the Village , it is also still focused on physical development activities 
Yunita Dewi Rahmawati, Ratna Dewi, Ainun Mardiah| Pengelolaan Dana Desa untuk Pemberdayaan Masyarakat Desa Mulya Subur Kecamatan Pangkalan Lesung Kabupaten Pelalawan

\section{PENDAHULUAN}

Kemiskinan merupakan salah satu masalah yang tidak pernah lepas dalam kehidupan masyarakat. Dari data Badan Pusat Statistik Indonesia jumlah penduduk miskin pada September 2019 tercatat sebesar 24,79 juta orang dan pada Maret 2020 tercatat sebesar 26,42 juta orang. Sedangkan dari data terbaru yang dikutip dari KOMPAS.com, pada September 2020 jumlah masyarakat miskin meningkat menjadi 27,55 juta orang. Hal ini memperlihatkan bahwa masalah kemiskinan yang terus bertambah setiap tahunnya.

Untuk menekan angka kemiskinan di Indonesia yang terus mengalami peningkatan serta jumlah penduduk yang juga terus bertambah, perlu kiranya pemerintah melakukan upaya-upaya dalam mensejahterakan masyarakat Indonesia. Mengingat jumlah penduduk yang tidak sedikit serta tersebar di 34 Provinsi di Indonesia, maka dengan adanya otonomi daerah sangat membantu untuk mewujudkan kesejahteraan masyarakat Indonesia.

Dalam upayanya untuk mensejahterakan masyarakat, desa diberi kewenangan untuk mengelola keuangan desa. Menurut Permendagri No. 113 Tahun 2014 tentang Pengelolaan Keuangan Desa, pengelolaan keuangan desa merupakan seluruh kegiatan yang meliputi perencanaan, pelaksanaan, penatausahaan, pelaporan dan pertanggungjawaban keuangan desa. Desa dituntut untuk mampu memanfaatkan Dana Desa yang dikelola dengan baik, menyusun perencanaan dan melaksanakan program sesuai dengan prioritas yang telah ditetapkan yaitu program yang bertujuan guna pembangunan desa dan pemberdayaan masyarakat desa.

Hal ini didasari oleh Peraturan Menteri Desa, Pembangunan Daerah Tertinggal, Dan Transmigrasi Republik Indonesia Nomor 16 Tahun 2018 tentang Prioritas Penggunaan Dana Desa Tahun 2019 Pasal 4 Ayat (1) yang berbunyi "Penggunaan Dana Desa diprioritaskan untuk membiayai pelaksanaan program dan kegiatan di bidang pembangunan Desa dan pemberdayaan masyarakat Desa". Dengan pemanfaatan Dana Desa yang diprioritaskan untuk pembangunan dan pemberdayaan tersebut diharapkan dapat memberikan manfaat sebesar-besarnya untuk masyarakat Desa demi meningkatkan kualitas hidup, peningkatan kesejahteraan dan penanggulangan kemiskinan serta peningkatan pelayanan terhadap masyarakat Desa.

Mulya Subur merupakan salah satu desa yang ada di Kecamatan pangkalan Lesung, Kabupaten Pelalawan, Provinsi Riau. Kepadatan jumlah penduduk di Desa Mulya Subur adalah 1.566 jiwa dengan jumlah rumah tangga mencapai 402 rumah tangga (BPS Kabupaten Pelalawan, 2021).

Jumlah masyarakat yang terdata miskin di Desa Mulya Subur pada tahun 2018 tercatat sejumlah $71 \mathrm{KK}$, jumlah ini meningkat pada tahun 2019 berjumlah $134 \mathrm{KK}$, dan di tahun 2020 terjadi penambahan jumlah masyarakat miskin kembali menjadi 139 KK. Hal ini menunjukkan adanya peningkatan jumlah masyarakat miskin pada 3 (tiga) tahun terkahir di Desa Mulya Subur (Kantor Desa Mulya Subur, 2021).

Desa Mulya Subur merupakan salah satu Desa yang menerima Dana Desa yang berasal dari Anggaran Pendapatan dan Belanja Negara (APBN). Dana Desa yang diterima Desa Mulya Subur bertambah tiap tahunnya. Hal ini dapat dilihat pada tabel tahun 2018 hingga 2020 jumlah Dana Desa yang diterima mengalami penambahan. Begitupun anggaran untuk pemberdayaan masyarakat juga mengalami peningkatan pada tahun 2018 hingga 2019, namun di tahun 2020 anggaran untuk pemberdayaan ditiadakan dan dialihkan untuk penanganan virus covid-19 sehingga program pemberdayaan masyarakat pada tahun 2020 juga tidak ada (Kantor Desa Mulya Subur, 2021).

Untuk menangani kasus kemiskinan yang ada di Desa Mulya Subur, pemerintah Desa mengadakan program pemberdayaan masyarakat dengan maksud untuk memandirikan masyarakat demi kesejahteraannya. Pemberdayaan masyarakat adalah proses pembangunan dimana masyarakat berinisiatif untuk memulai proses kegiatan sosial demi memperbaiki situasi dan kondisi diri sendiri. Menurut UU Nomor 6 Tahun 2014 Tentang Desa, Ketentuan Umum Pasal 1 ayat 12 bahwa Pemberdayaan masyarakat desa adalah upaya mengembangkan kemandirian dan kesejahteraan dengan meningkatkan pengetahuan, sikap, keterampilan, perilaku, kemampuan, kesadaran, serta memanfaatkan sumber daya melalui penetapan kebijakan, program, kegiatan, dan pendampingan yang sesuai dengan esensi masalah dan prioritas kebutuhan masyarakat 
Yunita Dewi Rahmawati, Ratna Dewi, Ainun Mardiah| Pengelolaan Dana Desa untuk Pemberdayaan Masyarakat Desa Mulya Subur Kecamatan Pangkalan Lesung Kabupaten Pelalawan

desa. Pemberdayaan masyarakat Desa merupakan upaya meningkatkan taraf hidup dan kesejahteraan masyarakat Desa melalui penetapan kebijakan, program, dan kegiatan yang sesuai dengan esensi masalah dan prioritas kebutuhan masyarakat Desa. Pemberdayaan ini menekankan pada proses memberikan atau mengalihakan sebagian kekuasaan, kekuatan atau kemampuan kepada masyarakat agar menjadi individu yang lebih berdaya. Pemberdayaan juga merupakan sebagai proses menstimulasi, mendorong atau memotivasi individu agar mempunyai kemampuan atau keberdayaan untuk menentukan apa yang menjadi pilihannya.

Dengan adanya pengelolaan Dana Desa (DD) yang baik untuk membiayai pelaksanaan pemberdayaan masyarakat desa, diharapkan akan menciptakan masyarakat yang sejahtera serta mampu meningkatkan perekonomiannya secara mandiri. Program pemberdayaan yang dilakukan untuk menangani kemiskinan di Desa Mulya Subur adalah pemberdayaan masyarakat di bidang ekonomi yang di tujukan kepada masyarakat miskin serta masyarakat umum Desa yang diharapkan dengan adanya program pemberdayaan tersebut masyarakat akan menjadi lebih mandiri dan juga sejahtera. Hal ini dapat dilihat pada tabel tersebut di atas yang menunjukkan besaran anggaran paling banyak dikeluarkan pada tahun 2019. Anggaran pemberdayaan masyarakat pada tahun 2020 dialihkan untuk penanganan covid-19 sehingga kegiatan untuk pemberdayaan tidak ada.

Adapun bentuk program pemberdayaan di bidang ekonomi tersebut adalah kelompok usaha ekonomi produktif, yang mana kegiatan yang dilakukan dalam pemberdayaan berupa pelatihan pembuatan keripik buah yang melibatkan kelompok ibu-ibu. Ekonomi kreatif merupakan konsep yang digunakan dalam merealisasikan pembangunan ekonomi yang berkelanjutan dan berbasis kreativitas. Modal utama yang diandalkan dalam ekonomi kreatif adalah sumber daya manusia, terutama untuk proses penciptaan, kreativitas, keahlian dan talenta individual. Dengan adanya pelatihan pembuatan keripik buah tersebut masyarakat akan mampu menumbuhkan dan meningkatkan kreativitasnya sehingga masyarakat dapat merubah kehidupannya kearah yang lebih baik.

Dari hasil pelatihan pembuatan keripik buah tersebut diharapkan akan mampu membuat usaha produk olahan sendiri melalui kelompok maupun individu, dengan memanfaatkan sumber daya yang ada di Desa tersebut baik itu bahan baku maupun tenaga kerja. Hasil dari produk olahan tersebut dapat menjadi produk unggulan dari Desa Mulya Subur, sehingga masyarakat tidak hanya berdaya namun juga memiliki penghasilan untuk membantu meningkatkan perekonomiannya. Dengan begitu permasalahan kemiskan akan berkurang.

Namun berdasarkan observasi peneliti, hingga kini apa yang diharapkan belum tampak wujudnya. Pengembangan hasil pelatihan baik itu berupa kelompok maupun individu hingga kini belum ada yang membuka usaha. Hal ini berdasar pula pada kutipan wawancara dari Kepala Desa Mulya: "Iya prospek kedepannya kan mbikin usaha gitukan setelah pelatihan keripik buah ini berhasil, jadi masyarakat terbantu ekonominya tapi ya itu, setelah dievaluasi jugak kemauan dari masyarakatnya untuk mengembangkan hasil pelatihan itu nggak ada, jadi kan gimana mau bisa lanjut kan".

Tidak hanya itu, untuk hal tersebut peneliti juga melakukan wawancara dengan masyarakat yang menjadi peserta pelatihan yaitu ibu Wahidah, ungkap beliau: "Habis ikut pelatihan itu ya sekarang aku nggak buka usaha sendiri mbak, takut nanti nggak balek modal to". (Wawancara, 09 Februari 2021).

Dengan demikian mengingat jumlah masyarakat miskin di Desa Mulya Subur yang juga bertambah setiap tahunnya serta penerimaan Dana Desa (DD) yang juga bertambah, peneliti tertarik untuk menganalisa pengelolaan Dana Desa (DD) di Desa Mulya Subur dengan memfokuskan penelitian ini pada penerapan asas pengelolaan keuangan Desa yang juga termasuk di dalamnya adalah Dana Desa (DD) untuk pemberdayaan masyarakat.

Berdasarkan uraian latar belakang, maka masalah yang dikemukakan adalah bagaimana pengelolaan Dana Desa (DD) untuk pemberdayaan masyarakat di Desa Mulya Subur Kecamatan Pangkalan Lesung Kabupaten Pelalawan dan apa saja faktor penghambat dalam pengelolaan Dana Desa (DD) untuk pemberdayaan masyarakat di Desa Mulya Subur Kecamatan Pangkalan Lesung Kabupaten Pelalawan.

\section{METODE PENELITIAN}

Jenis penelitian yang digunakan berjenis penelitian kualitatif. Sumber data yang digunakan dua jenis data, yaitu data primer dan data sekunder. Data primer adalah data yang 
Yunita Dewi Rahmawati, Ratna Dewi, Ainun Mardiah I Pengelolaan Dana Desa untuk Pemberdayaan Masyarakat Desa Mulya Subur Kecamatan Pangkalan Lesung Kabupaten Pelalawan

dikumpulkan langsung oleh peneliti dari objeknya. Yang mana data primer disini diperoleh melalui pengamatan langsung di lapangan (observasi), hasil wawancara dan dokumentasi. Data sekunder adalah data yang diperoleh untuk melengkapi data primer yang didapat dari instansi yang bersangkutan. Yang mana data sekunder disini diperoleh melalui catatan-catatan yang dimiliki instansi serta data lainnya yang mendukung penelitian ini. Dalam penelitian ini, teknik pengumpulan data yang dilakukan peneliti adalah Observasi, Wawancara dan Dokumentasi. Informan penelitian adalah orang-orang yang dapat memberikan informasi terkait data yang dibutuhkan oleh peneliti. Untuk mendapatkan informan, peneliti meminta bantuan informan yang sudah diperoleh informasinya untuk memilih orang yang dipandang mengetahui informasi yang dibutuhkan. Pemilihan para informan ini dilakukan sesuai dengan pendapat Patton (2001), bahwa memilih informan harus yang dianggap paling tahu, sehingga pemilihan seimbang sesuai dengan kebutuhan dan kemantapan peneliti. Adapun informan dalam penelitian ini meliputi: Kepala Desa Mulya Subur, Kaur Keuangan Desa Mulya Subur, Kasi Pelayanan Desa Mulya Subur, Ketua BPD Desa Mulya Subur, Ketua RT dan Warga masyarakat Desa Mulya Subur. Analisis data yakni mengelola hasil penelitian menjadi data, dimana data yang diperoleh dikerjakan dan dimanfaatkan sedemikian rupa sehingga dapat menyimpulkan persoalan yang diajukan dalam menyusun hasil penelitian. Pada penelitian ini analisis data yang dilakukan menggunakan model Miles dan Hubermen (1984) yakni melalui 3 (tiga) tahap, yaitu reduksi data, penyajian data dan menarik kesimpulan.

\section{HASIL DAN PEMBAHASAN}

Pengelolaan Dana Desa Untuk Pemberdayaan Masyarakat Di Desa Mulya Subur Kecamatan Pangkalan Lesung Kabupaten Pelalawan

Dalam Permendagri No. 113 Tahun 2014 tentang Pengelolaan Keuangan Desa, pengelolaan keuangan Desa ialah keseluruhan kegiatan yang meliputi perencanaan, pelaksanaan, penatausahaan, pelaporan dan pertanggungjawaban keuangan Desa. Sedangkan keuangan Desa ialah semua hak dan kewajiban Desa yang dapat dinilai dengan uang serta segala sesuatu berupa uang dan barang yang berhubungan dengan pelaksanaan hak dan kewajiban Desa.

Pada penelitian ini, pembahasan mengenai hasil penelitian yang akan dipaparkan ialah mengenai pengelolaan keuangan Desa yakni Dana Desa (DD) dengan memfokuskan pada indicator asas pengelolaan keuangan Desa yang tertuang dalam Permendagri No. 113 tahun 2014 tentang Pengelolaan Keuangan Desa yakni transparan, akuntabel, partisipatif serta tertib dan disiplin anggaran. Dana Desa (DD) sendiri merupakan dana APBN (Anggaran Pendapatan dan Belanja Negara) yang diperuntukkan bagi Desa yang ditransfer melalui APBD (Anggaran Pendapatan dan Belanja Daerah) Kabupaten/Kota dan diprioritaskan untuk pelaksanaan pembangunan dan pemberdayaan masyarakat Desa.

Desa Mulya Subur adalah salah satu desa di Kecamatan Pangkalan Lesung Kabupaten Pelalawan yang menerima Dana Desa tiap tahunnya. Dana Desa yang diterima Desa Mulya Subur tiap tahunnya mengalami peningkatan jumlah, yakni pada tahun 2019 Dana Desa yang diterima berjumlah $\mathrm{Rp}$. 841.298.000, dan di tahun 2020 Dana Desa yang diterima bertambah jumlahnya menjadi Rp. 846.025.000 (Kantor Desa Mulya Subur, 2021).

Dari hasil penelitian mengenai analisa terhadap pengelolaan Dana Desa untuk pemberdayaan masyarakat di Desa Mulya Subur, akan dipaparkan bagaimana pengelolaan Dana Desa Di Desa Mulya Subur. Dengan melihat pada indikator Asas pengelolaan keuangan desa yang tertuang dalam Permendagri No. 113 tahun 2014 tentang pengelolaan keuangan desa yakni transparan, akuntabel, partisipatif serta tertib dan disiplin anggaran.

\section{Transparan}

Dalam penerapan asas transparansi, pada tahap perencanaan pengelolaan Dana Desa masyarakat turut terlibat mengikuti musyawarah mengenai perencanaan pengelolaan Dana Desa di Desa Mulya Subur. Hal ini dibuktikan dengan pernyataan dari Kaur Keuangan, beliau mengungkapkan: "Ya waktu perencanaan nantikan Tim sebelas itu mengajukan ke BPD tentang perencaaan kegiatan, nah setelah kita ajukan ke BPD, maka BPD itu nanti mengadakan musyawarah ke masyarakat, di situlah nanti apa-apa kira-kira 
Yunita Dewi Rahmawati, Ratna Dewi, Ainun Mardiah I Pengelolaan Dana Desa untuk Pemberdayaan Masyarakat Desa Mulya Subur Kecamatan Pangkalan Lesung Kabupaten Pelalawan

masyarakat setuju atau enggak di situlah keputusannya". (Wawancara, 06 Mei 2021).

Berdasarkan ungkapan beliau, bahwa dalam proses perencanaan ada yang disebut sebagai Tim sebelas. Dalam Permendagri No. 114 tahun 2014 pasal 33 tim sebelas merupakan tim yang dibentuk oleh kepala desa sebagai Tim penyusun RKP Desa (Rencana Kegiatan Pembangunan Desa), yang mana tim tersebut ditentukan paling sedikit 7 (tujuh) orang dan paling banyak adalah 11 (sebelas) orang. Di Desa Mulya Subur sendiri, dalam penentuan Tim penyusun RKP Desa ditetapkan sebanyak 11 (sebelas) orang. Tim inilah yang nantinya membantu dalam penyusunan RKP Desa dengan dibantu oleh BPD (Badan Permusyawaratan Desa) untuk menggali aspirasi dari masyarakat mengenai rencana kegiatan yang akan dilakukan dalam satu tahun anggaran. Hasil dari musyawarah-musyawarah tersebut yang nantinya akan disusun oleh Tim 11 (sebelas) menjadi RKP Desa.

Dari sini dapat diketahui bahwa dalam proses perencanaan masyarakat juga dilibatkan untuk mengikuti musyawarah, dalam artian pemerintah Desa dalam perencanaan terbuka dengan masyarakat sehingga masyarakat mengetahui rencana apa yang akan dilakukan di Desa Mulya Subur. Tidak hanya itu, pemerintah Desa juga mengedepankan kesepakatan dari masyarakat atas perencanaan untuk pengelolaan Dana Desa (DD) tersebut, sehinga kegiatankegiatan yang lakukan sudah atas persetujuan bersama. Hal ini juga diperkuat dengan pernyataan dari Ketua RT 003, beliau mengungkapkan: "Ya itu pas musyawarah, tingkat RT, RW ikut diundang di kantor Desa gitu termasuk tokoh masyarakat. Dibahas di situ apa dan rencananya dana itu untuk apa udah tercantum di situ". (Wawancara, 03 Mei 2021).

Pada tahap pelaksanaan pun dalam hal ini kegiatan pemberdayaan, masyarakat dapat mengawasi kegiatan yang sedang berlangsung. Dari pengawasan secara langsung tersebut, masyarakat dapat mengetahui bahwa benar adanya apa yang sudah direncanakan pada kegiatan pemberdayaan ketika awal perencanaan sedang dilaksanakan, dan di situ pula masyarakat dapat mengetahui apa saja kendala yang terjadi selama pelaksanaan kegiatan berlangsung. Hal ini di nyatakan oleh Tim Pelaksana Kegiatan Pemberdayaan, beliau mengungkapkan: "Selama kegiatan pelatihan berlangsung kan, baik itu pesertanya maupun yang bukan peserta maksudnya masyarakat yang pengen liat kegiatan pelatihannya aja itukan tau, oh ini kegiatan pemberdayaannya kayak gini to, oh kurangnya atau mungkin kendalanya ini, jadi tau langsung mereka dilapangan". (Wawancara, 09 Februari 2021).

Hal ini pun turut didukung dengan pernyataan dari masyarakat selaku peserta yang mengikuti pemberdayaan pelatihan membuat keripik buah yakni ibu Peni, beliau mengatakan: "Pas pelatihan mbikin keripik buah itu to, ikut mbak. Ya selama pelatihan tau gitu proses mbuatnya kayak mana kan tau nanti alat bahanbahannya apa aja untuk mbuat dikasih tau". (Wawancara, 09 Februari 2021).

Sedangkan pada tahap penatausahaan, Desa sudah menggunakan aplikasi Siskeudes. (Sistem Keuangan Desa). Aplikasi ini merupakan aplikasi pengelolaan keuangan Desa yang dikembangkan oleh Badan Pengawas Keuangan dan Pembangunan (BPKP). Aplikasi ini merupakan alat bantu bagi pemerintah Desa untuk mengelola kauangan Desa secara komputerisasi. Kaitannya dengan transparansi adalah aplikasi ini merupakan aplikasi resmi pemerintah yang dapat diintegrasikan dengan aplikasi SIPEDE milik Kementrian Desa Pembangunan Daerah Tertinggal dan Transmigrasi (Kemendesa PDTT). Aplikasi SIPEDE sendiri merupakan system aplikasi monitoring yang digunakan Kementrian Desa untuk memantau dan monitoring pengelolaan Dana Desa secara terintegrasi dan kontinyu pada program pembangunan dan pemberdayaan masyarakat Desa sehingga tata kelola keuangan Desa lebih transparan. Informasi ini dikutip dari situs resmi BPKP www.bpkp.go.id. Hal ini pun dapat didukung dari pernyataan Kaur Keuangan yang memegang aplikasi Siskeudes, beliau mengungkapkan: "Ya kita kan ada aplikasi Siskeudes, di aplikasi itu sudah diatur apa-apa aja yang boleh dibangun pos-posnya jadi kita nggak bisa melenceng dari Siskeudes itu sendiri. Jadinya sesuai aturan karna kalo mau melenceng pun nggak ada posnya kita nggak bisa menganggarkan. Masyarakat pun kalau misal pengen minta datanya kita kasih, tapi sejauh ini masyarakat nggak ada yang sampai minta data dari aplikasi soalnya udah ada baliho kan jadi ya mereka ngeliat di situ". (Wawancara, 05 Mei 2021).

Beliau juga turut mengatakan bahwa pemerintah Desa melayani masyarakat yang datang denga tujuan meminta data dalam aplikasi tersebut. Hanya saja sejauh ini masyarakat hanya memanfaatkan baliho yang 
Yunita Dewi Rahmawati, Ratna Dewi, Ainun Mardiah| Pengelolaan Dana Desa untuk Pemberdayaan Masyarakat Desa Mulya Subur Kecamatan Pangkalan Lesung Kabupaten Pelalawan

dipasang untuk mengetahui pengelolaan keuangan Desa terutama Dana Desa (DD).

Pada tahap pelaporan dan pertanggungjawaban pun, pemerintah Desa sudah menerapkan transparansi terutama kepada pihak masyarakat sendiri. Seperti yang diungkapkan oleh Kepala Desa, beliau menyatakan: "Untuk itu kita udah ada papan informasi ya itu di depan, untuk pemberdayaan jugak ada di situ. Trus kan kita jugak adakan musyawarah sama masyarakatnya juga gitu untuk menyampaikan itu tadi". (Wawancara, 03 Mei 2021).

Dari keterangan yang diberikan oleh Kepala Desa dapat diketahui bahwa dalam penerapan asas transparansi untuk memudahkan masyarakat Desa mengetahui laporan pertanggungjawaban pengelolaan Dana Desa, Desa menyampaikan laporan pertanggungjawaban realisasi keseluruhan anggaran termasuk Dana Desa melalui musyawarah dengan melibatkan masyarakat tentu saja.

Tidak hanya itu, laporan realisasi penggunaan anggaran juga diinformasikan secara tidak langsung yakni berupa pemasangan papan informasi atau baliho. Untuk membuktikan itu, peneliti pun melakukan observasi di lokasi tempat pemasangan papan informasi yang diarahkan oleh Kepala Desa.

Dari hasil observasi peneliti untuk membuktikan adanya papan informasi tersebut, terbukti memang benar adanya bahwa papan informasi tersebut terpasang tepat di depan gor. Lokasi tempat pemasangan papan informasi tersebut masih termasuk di lingkungan kantor Desa yang mana lokasi tempat pemasangan berada di pinggir jalan utama bagi masyarakat yang ingin keluar masuk Desa. Tidak hanya Dana Desa saja, namun semua keuangan Desa yang dikelola tercantum pada papan informasi tersebut.

Hal ini diperkuat oleh pernyataan dari Kaur Keuangan, beliau mengatakan: "Transparansi kita menerapkan, bukan Cuma Dana Desa saja tapi semuanya, itu contohnya papan informasi mengenai pendapatan, belanja itu ada disitu semua berapa jumlahnya pokoknya setiap pembangunan apa aja termasuk pemberdayaan jugak ada itu di depan situ". (Wawancara, 06 Mei 2021).

Dari hasil wawancara dan observasi untuk melihat penerapan transparansi dalam pengelolaan Dana Desa (DD) terutama untuk pemberdayaan masyarakat di Desa Mulya
Subur dapat diketahui sudah baik. Dari mulai tahap perencanaan pemerintah Desa selalu melibatkan BPD, lembaga Desa, serta masyarakat dengan melakukan musyawarah. Pada tahap pelaksanaan pun masyarakat dapat melihat secara langsung kegiatan-kegiatan yang dijalankan sesuai yang telah direncanakan. Kemudian pada tahap penatausahaan pemerintah telah dibekali dengan aplikasi SISKEUDES yang mana juga pada system aplikasi tersebut sudah terhubung langsung dengan aplikasi khusus yang dipegang oleh Kemendesa PDTT untuk memonitoring.

\section{Akuntabel}

Dalam pengelolaan keuangan Desa yang termasuk di dalamnya Dana Desa (DD), asas akuntabel sangat penting untuk diterapkan sebagai bentuk pertanggungjawaban pemerintah Desa atas kinerjanya dalam mengelola apa yang dipercayakan oleh dan demi kesejahteraan masyarakat Desa. Pada penerapan asas akuntabel dalam pengelolaan Dana Desa (DD) untuk pemberdayaan masyarakat di Desa Mulya Subur, peneliti mewawancarai Kepala Desa. Beliau mengungkapkan: "Pertanggungjawabannya ya kita bikin laporan di LPJnya itu kan ada itu. Kalau keterlambatan ndak ada kita sesuai jadwalnya karna pencairan itukan kegiatan apa yang dah dianggarkan tu suruh nyiapkan dulu biar nanti untuk pencairan tahap berikutnya kan gitu. Ibaratnya ini kan tahap pertama ndak ada pelatihan untuk pemberdayaan ya pekerjaannya harus dilaksanakan dulu nanti kalo udah selesai untuk nyairkan dana yang ke dua itu harus dilaporkan dulu kegiatannya kan gitu". (Wawancara, 06 Mei 2021).

Dari apa yang disampaikan oleh Kepala Desa di atas, peneliti dapat mengetahui bahwa sebagai bentuk pertanggungjawaban pemerintah Desa dalam mengelola keuangan Desa termasuk Dana Desa (DD) yakni dengan membuat laporan pertanggungjawaban yang disebut dengan LPJ. Pemerintah Desa Mulya Subur menyelesaikan laporan pertanggungjawaban dengan tepat waktu. Hal ini dikarenakan setiap pencairan dana memerlukan persyaratan berupa laporan realisasi anggaran kegiatan yang sebelumnya. Seperti yang diungkapkan oleh Kepala Desa tersebut bahwa pada anggaran kegiatan tahap awal yang telah terlaksana lalu dibuat laporan realisasinya. Hasil laporan realisasi kegiatan di tahap awal itu kemudian dilaporkan ke 
Yunita Dewi Rahmawati, Ratna Dewi, Ainun Mardiah I Pengelolaan Dana Desa untuk Pemberdayaan Masyarakat Desa Mulya Subur Kecamatan Pangkalan Lesung Kabupaten Pelalawan

Kabupaten/Kota sebagai syarat pencairan anggaran di tahap yang ke dua.

Berdasarkan peraturan tersebut mekanisme dalam penyaluran Dana Desa dilakukan secara bertahap mulai dari pusat (APBN) ke Kabupaten/Kota (APBD), hingga ke Desa (APBDesa). Penyaluran Dana Desa dilakukan dengan 2 (dua) tahap, disetiap tahapannya juga memerlukan persyaratan yang berbeda baik penyaluran dari APBN ke APBD hingga penyaluran dari APBD ke APBdesa. Mengingat pada penelitian ini memfokuskan pada pemerintah Desa, maka peneliti akan membatasi hanya pada penyaluran Dana Desa dari APBD ke APBDesa saja agar tidak semakin luas.

Dalam pengelolaan Dana Desa (DD), agar asas akuntabel dapat terwujud serta untuk memastikan capaian penggunaan Dana Desa (DD), proses penyaluran Dana Desa (DD) memerlukan persyaratan-persyaratan yakni berupa laporan APBDesa. Meskipun tiap-tiap tahapan penyaluran memerlukan persyaratan laporan realisasi APBDesa, namun laporan realisasi APBDesa dimasing-masing tahap penyaluran berbeda. Adapun syarat penyaluran Dana Desa (DD) tahap I yakni berupa laporan realisasi Dana Desa pada tahun sebelumnya. Sedangkan untuk penyaluran Dana Desa (DD) tahap II syarat yang harus terpenuhi berupa laporan realisasi Dana Desa (DD) tahap I (satu). Laporan-laporan yang dipertanggungjawabkan oleh pemerintah Desa baik itu tahap I maupun tahap II ini disebut dengan laporan semester pertama dan laporan semester kedua atau akhir tahun.

Tidak hanya berhenti sampai di situ, tambahan informasi juga peneliti dapat dari Kaur Keuangan, beliau mengungkapkan: "Pada tahap pelaporan biasanya pelaporan tentang nggak khusus DD aja ya semua nih biasanya itu per 31 Desember itu pelaporan kita udah selesai, sudah tersusun, tepat waktu. Tapi biasanya orang Kabupaten itu mintak pertanggungjawabannya itu nggak mungkin tanggal 31 pas, karna tanggal 31 itu kita baru tutup buku. Biasanya itu tanggal 5, itu namanya LPJ laporan pertanggungjawaban tahunan itu biasanya itu udah kita kumpulkan itu udah jadi barangnya. Tanggal 5 an, tanggal 10 Januari itu sudah ready barangnya. Pemeriksanaan inspektorat pun biasanya itu kadang memang nggak bisa dipastikan jugak ya, kadang itu dia datang inspektorat tu Januari awal Januari pertengahan lah, seringnya itu pertengahan akhir itu dah datang. Kadang dibulan Maret tergantung mereka mau ke Desa mana dulu lah". (Wawancara, 06 Mei 2021).

Dari wawancara peneliti dengan Kaur Keuangan dapat diketahui bahwa pemerintah Desa Mulya Subur pada tahap pelaporan dilakukan tepat waktu yakni per 31 Desember. Sehingga ketika pihak-pihak yang ingin meminta pertanggungjawaban seperti pihak inspektorat yang membantu tugas Bupati sebagai pengawas pelaksanaan urusan pemerintahan laporan tersebut telah tersedia.

Adapun laporan pertanggungjawaban disampaikan paling lambat 3 (tiga) bulan setelah akhir tahun anggaran berkenaan yang ditetapkan dengan Perdes. Perdes yang dimaksud disertai dengan laporan keuangan, laporan realisasi kegiatan, serta daftar program sektoral, daerah dan lainnya yang masuk ke Desa. Selain itu, dalam penyusunan laporan pertanggungjawaban pengelolaan keuangan Desa pemerintah Desa sudah menggunakan aplikasi Siskeudes (Sistem Keuangan Desa). Sehingga memudahkan pemerintah untuk menyelesaikan laporan-laporan pertanggungjawabannya, termasuk di dalamnya mengenai Dana Desa (DD) untuk pemberdayaan masyarakat.

Tidak hanya kepada Bupati/Wali Kota saja, pertanggungjawaban juga disampaikan kepada masyarakat Desa yang memuat laporan realisasi APBDesa, realisasi kegiatan, kegiatan yang belum selesai dan/atau yang tidak terlaksana, serta sisa anggaran baik secara langsung maupun tidak langsung. Pelaporan pertanggungjawaban realisasi anggaran secara langsung yakni melalui musyawarah, sedangkan pelaporan secara tidak langsung dapat melalui papan informasi maupun media informasi lainnya yang mudah diakses oleh masyarakat. Di Desa Mulya Subur sendiri sebagai bentuk pertanggungjawaban pemerintah kepada masyarakat dalam pengelolaan keuangan Desa termasuk Dana Desa (DD) yakni dilakukan secara langsung dan tidak langsung. Pertanggungjawaban secara langsung dilakukan dengan menggelar rapat musyawarah serta secara tidak langsung dengan memanfaatkan papan informasi yang dipasang ditempat umum yang mudah dijangkau masyarakat.

Dengan begitu dapat diketahui bahwa penerapan asas akuntabel di Desa Mulya Subur dalam pengelolaan keuangan Desa terutama pada penelitian ini adalah Dana Desa (DD) 
Yunita Dewi Rahmawati, Ratna Dewi, Ainun Mardiah| Pengelolaan Dana Desa untuk Pemberdayaan Masyarakat Desa Mulya Subur Kecamatan Pangkalan Lesung Kabupaten Pelalawan

untuk pemberdayaan masyarakat sudah dilakukan dengan baik. Pemerintah Desa mempertanggungjawabkan pengelolaan keuangan Desa terutama Dana Desa (DD) untuk pemberdayaan masyarakat dengan membuat laporan pertanggungjawaban sesuai aturan yang berlaku. Tidak hanya itu pemerintah Desa juga tidak hanya mempertanggungjawabkannya ke Kabupaten/Kota saja, melainkan kepada masyarakat umum di Desa Mulya Subur dengan menggelar musyawarah serta memasang papan informasi di tempat umum untuk memudahkan masyarakat sekitar yang ingin melihat.

\section{Partisipatif}

(Harun \& Ardianto, dalam Kusumadinata 2015:87) mengatakan bahwa partisipatif adalah pengambilan keputusan, pengambilan bagian/pengikut-sertaan. Secara umum dapat dikatakan bahwa partisipatif merupakan keikutsertaan aktif dari orang ataupun kelompok dalam mengikuti suatu kegiatan baik dari perencanaan, pelaksanaan hingga pengawasan.

Dalam pengelolaan secara keseluruhan keuangan Desa yang termasuk di dalamnya Dana Desa (DD) untuk pemberdayaan masyarakat, asas partisipatif sangat penting. Partisipasi besar dari masyarakat untuk ikut berperan aktif dalam pengelolaan keuangan Desa terutama Dana Desa (DD) sangat diperlukan. Terutama dalam hal ini adalah pemberdayaan masyarakat, sebab masyarakatlah yang paling mengetahui mengenai permasalahan serta kebutuhannya untuk mencapai kesejahteraan bersama.

Untuk itu peneliti mencari informasi melalui wawancara dengan Kepala Desa, beliau mengungkapkan: "Untuk perencanaan itukan ada musyawarah Desa atau Musdus ya itu makanya kalok ibaratnya musyawarah Dusun atau Musdus nah itukan ada masyarakat mengajukan untuk pemberdayaan kan gitu, makanya dari bawahnya tu ya itu dari musyawarah Dusun itu mengajukan ibaratnya minta permintaan untuk pelatihan apa kan gitu. Itu pun ya nggak semua permintaan dikabulkan karna disesuaikan dengan dananya jugak kan apalagi sesuai dengan kondisi, memang bahan atau apa itu yang ada di butuhkan dimasyarakat sp 7. Kalo untuk kedepannya untuk pemberdayaan nanti saya rencanakan dari kelompok atau perorangan kalo minta untuk pemberdayaan mengajukan proposal gitu loh, otomatis ibaratnya kalok kelompok itu mengajukan proposal berarti kelompok itu butuh kan gitu, cuman nanti kalok ibaratkan bisa ngasih belum tentu masyarakat itu perlu kan gitu. Kalo yang sebelumnya memang desa yang mengadakan, kalo untuk kedepannya kita ubah nanti dari bawah minta kedesa gitu. Kalo partisipasi dari masyarakatnya ya tinggi kalo bisa kan minta semua, cuman kita kan terbatas anggaran dana otomatis anggotanya ya ditentukan gitukan. Ibaratnya orang sepuluh atau orang lima belas". (Wawancara: $03 \mathrm{Mei}$ 2021).

Dari pernyataan Kepala Desa peneliti dapat mengetahui bahwa dalam proses pengelolaan keuangan Desa terutama Dana Desa untuk pemberdayaan masyarakat pada tahap perencanaan untuk menentukan kegiatan apa yang akan dilakukan terlebih dahulu dilaksanakan musyawarah. Musyawarah yang dilakukan di Desa Mulya Subur dimulai dari tingkat Musdus (Musyawarah Dusun) untuk menjaring aspirasi dari masyarakat di lingkungan Dusun. Pada musyawarah dusun tersebut dibahas mengenai usulan-usulan masing-masing RT, RW, serta kelompok mayarakat sesuai dengan keadaan dan kebutuhan masing-masing dusun tersebut.

Tahap selanjutnya adalah musyawarah Desa, yang mana pada musyawarah ini membahas mengenai penentuan jenis kegiatan yang menjadi prioritas usulan dari masingmasing dusun. usulan yang telah disepakati untuk menjadi prioritas akan dibahas bersama kembali dalam Musrenbangdes (Musyawarah rencana pembangunan Desa).

Tahap Musrenbangdes merupakan tahap inti yang mana pada musyawarah ini sebagai penentuan berbagai program dan kegiatan yang menjadi prioritas untuk dilaksanakan nantinya. Disini juga partisipasi dari masyarakat sangat dibutuhkan untuk menentukan prioritas kegiatan baik pembangunan maupun pemberdayaan dalam satu tahun anggaran dengan berpedoman dari hasil Musdus yang sudah dirangkum menjadi prioritas usulan dalam Musdes. Hasil akhir dari musyawarah ini adalah tersusunnya RKPDes (Rencana Kerja Pemerintah Desa) untuk satu tahun anggaran.

Dari sini dapat diketahui bahwa partisipasi dari masyarakat pada tahap perencanaan sangat antusias dengan turut menghadiri setiap musyawarah yang dilaksanakan di Desa. Namun dari wawancara tersebut juga peneliti menemukan kekurangan, berdasarkan ungkapan dari Kepala Desa bahwa pada 
Yunita Dewi Rahmawati, Ratna Dewi, Ainun Mardiah| Pengelolaan Dana Desa untuk Pemberdayaan Masyarakat Desa Mulya Subur Kecamatan Pangkalan Lesung Kabupaten Pelalawan

perencanaan program pemberdayaan masyarakat merupakan kebijakan atau ditentukan oleh pemerintah Desa (Top-Down), bukan merupakan gagasan perencanaan dari masyarakat sendiri (Buttom-Up). Sedangkan untuk merubah kondisi masyarakat, merekalah yang paling tahu masalah dan kebutuhannya.

Menurut Warjio (2016: 178-180) pendekatan Top-Down merupakan pendekatan yang berpusat pada "actor atas". Sedangkan pendekatan Buttom-Up merupakan pendekatan yang berasal dari bawah. Dalam bukunya juga dikatakan bahwa pendekatan Buttom-Up merupakan strategi yang paling baik untuk mencapai keberhasilan pembangunan Desa. Hal ini dikarenakan masyarakat Desalah yang paling mengetahui kondisi-kondisi hidup mereka.

Lebih lanjut dikatakan bahwa pendekatan perencanaan Top-Down merupakan perencanaan yang dilakukan oleh pemerintah sedang masyarakat hanya sebagai penerima dan pelaksana. Selain itu pendekatan perencanaan Buttom-Up merupakan perencanaan yang didasarkan oleh kebutuhan dari masyarakat dan pemerintah hanya sebagai fasilitator (Munthe, et al., 2021: 68).

Selain itu di sini juga diketahui bahwa masyarakat juga tidak berinisiatif untuk mengkritik atau mengajukan program pemberdayaan yang sesuai dengan kondisi sendiri. Dengan demikian dapat dikatakan bahwa masyarakat Desa Mulya Subur dalam berpartisipasi masih bersikap pasif. Sedangkan dalam perencanaan suatu pembangunan, masyarakat dituntut untuk berpartisipasi aktif. Seperti yang dikatakan dalam Damsar dan Indrayani (2016: 229) bahwa pada partisipasi aktif seseorang turut serta dalam semua proses kegiatan yang ada dengan memberikan kontribusi sesuai dengan kapabilitas dan kompetensi yang dimiliki. Sedangkan dalam partisipasi pasif seseorang turut serta dalam suatu aktivitas secara sangat minimal, misalnya hanya sekedar hadir, tanpa memberi kontribusi apa pun. Hal ini sesuai dengan kutipan dari wawancara salah satu masyarakat yakni Bapak Atok, beliau menuturkan: "Pemberdayaan yang kayak pelatihan itu to, iya pas rapat waktu itu kan Desa katanya mau ngadakan itu, ya monggo ngikut aja, berarti kan pemerintah perduli sama masyarakatnya kalo mereka ngadain itu to". (Wawancara, 06 Mei 2021).

Dilain kesempatan peneliti juga melakukan wawancara dengan Kaur Keuangan, yang mana beliau mengungkapkan: "Masyarakat ya ikut berpartisipasi, contohnya seperti memantau ya, dalam pelaksanaan jugak sering kadang kayak sebagai pekerja kalok dalam bidang pembangunan ya kita selalu menggunakan orang-orang desa sendiri untuk melakukan pembangunan gitu, pemberdayaan pun ya sama setiap kegiatan masyarakat pasti ikut kayak pelatihan pembuatan keripik buah waktu itukan, cuma untuk pelatihnya sendiri kita datangkan dari luar". (Wawancara: 06 Mei 2021).

Dari pernyataan Kaur Keuangan tersebut dapat diketahui bahwa pada tahap pelaksanaan masyarakat turut serta mengikuti kegiatan yang dilakukan oleh Desa bahkan turut serta memantau keberlangsungan kegiatan yang dilakukan. Pada kegiatan pembangunan Desa, sebagai tenaga kerja yang melakukan pekerjaan pembangunan selalu menggunakan tenaga kerja dari masyarakat setempat. Sehingga masyarakat pun bias sekaligus memantau perkembangan dari pembangunan yang dilakukan.

Pada bidang pemberdayaan masyarakat yang menjadi focus penelitian ini pun partisipasi dari masyarakat juga antusias untuk mengikuti setiap kegiatan pemberdayaan yang diadakan di Desa. Sehingga baik masyarakat yang menjadi peserta kegiatan maupun di luar peserta kegiatan dapat pula berpartisipasi dengan memantau keberlangsungan dari kegiatan-kegiatan yang diadakan. Dalam hal ini kegiatan pemberdayaan masyarakat berupa pelatihan membuat keripik buah untuk menumbuh kembangkan kreativitas mandiri dari masyarakat terutama ibu-ibu. Sehingga hasil dari kegiatan pelatihan tersebut dapat diterapkan atau bahkan dikembangkan lagi oleh masyarakat itu sendiri untuk membantu meningkatkan perekonomiannya sehingga masyarakat dapat sejahtera secara mandiri. antusias dari masyarakat dalam mengikuti pemberdayaan pun dapat terlihat dengan ikut hadir pada sosialisasi kegiatan pelatihan pembuatan keripik buah sebelum kegiatan tersebut dilaksanakan.

Pada tahap pelaporan dan pertanggungjawaban, partisipasi masyarakat juga terlihat dengan menghadiri rapat penetapan LPJ (Laporan pertanggungjawaban). Rapat tersebut sebagai bentuk pertanggungjawaban pemerintah Desa dalam pengelolaan Dana Desa (DD) selama 1 (satu) tahun anggaran. Hal ini dibenarkan oleh Kepala Desa, beliau mengungkapkan: "Iya pelaporan biaya ibaratnya biaya habis berapa, pesertanya berapa 
Yunita Dewi Rahmawati, Ratna Dewi, Ainun Mardiah| Pengelolaan Dana Desa untuk Pemberdayaan Masyarakat Desa Mulya Subur Kecamatan Pangkalan Lesung Kabupaten Pelalawan

itu kan nanti di catat, terus kemudian nanti di akhir anggaran dibuat laporannya bareng masyarakat juga pas rapat. Jadikan di situ masyarakat secara langsung tau anggarannya untuk apa, habis berapa, hasilnya juga gimana". (Wawancara, 03 Mei 2021).

Dari hasil peneitian diketahui bahwa angaran Dana Desa (DD) yang di terima di Desa Mulya Subur selama 3 (tiga) tahun terakhir lebih banyak dimanfaatkan untuk anggaran pembangunan Desa. Sedangkan anggaran untuk pemberdayaan masyarakat selama 2 (dua) tahun terakhir yakni tahun 2018 dan 2019 terbilang paling sedikit, bahkan ditahun 2020 anggaran Dana Desa (DD) untuk pemberdayaan masyarakat tidak ada sebab dialihkan untuk penanganan darurat covid-19. Hal ini sesuai penuturan dari Kasi Pelayanan sekaligus Tim Pelaksana Kegiatan Pemberdayaan Masyarakat, ungkap beliau: "Iya tahun 2020 itu pemberdayaan ditiadakan karna kan tau sendiri bencana covid ni, jadi anggarannya itu dialihkan untuk itu, mau buat pemberdayaan kayak pelatihan pun kan pemerintah memberi kebijakan dilarang kumpul-kumpul ya akhirnya ditiadakan". (Wawancara, 03 Mei 2021).

Dari hasil wawancara dan beberapa dokumen pendukung yang peneliti dapatkan, dapat disimpulkan bahwa dalam pengelolaan Dana Desa (DD) untuk pemberdayaan masyarakat di Desa Mulya Subur masih dikatakan kurang dalam menerapkan asas partisipatif. Pada tahap perencanaan masyarakat turut aktif berpartisipasi mengikuti musyawarah baik itu Musdus, Musdes hingga Musrenbangdes yang diadakan oleh Desa. Hanya saja pada perencanaan tersebut, pemerintah masih kurang dalam membuka ruang bagi peran serta masyarakat dalam berpartisipasi. Hal ini dikarenakan pada perencanaan program pemberdayaan masyarakat masih atas prakarsa pemerintah saja. Bahkan masyarakat sendiri pun masih bersifat pasif, dalam artian masyarakat hanya menerima saja tanpa mengritik ataupun mengajukan program yang sesuai dengan kebutuhannya.

Pada tahap pelaksanaan masyarakat turut berpartisipasi mengikuti setiap kegiatan diadakan oleh pemerintah. Tidak hanya sebagai peserta kegiatan, namun masyarakat juga bebas ikut mengawasi jalannya kegiatan yang sedang berlangsung. Sedangkan pada tahap pelaporan dan pertanggungjawaban, partisipasi masyarakat sangat antusias dengan menghadiri rapat penetapan LPJ (Laporan Pertanggungjwaban). Dengan demikian asas partisipatif dalam pengelolaan keuangan Desa terutama Dana Desa (DD) untuk pemberdayaan masyarakat di Desa Mulya Subur telah diterapkan dengan baik.

\section{Tertip dan Disiplin Anggaran}

Pada pengelolaan keuangan Desa termasuk Dana Desa (DD) untuk pemberdayaan masyarakat, adanya tertib dan disiplin dalam anggaran sangat perlu. Sebagaimana tertib dan disiplin anggaran berarti dalam pengelolaan keuangan Desa harus mengacu pada aturan dan pedoman yang melandasinya. Maksudnya adalah dalam pengelolaan keuangan Desa harus dilakukan sesuai dengan prosedur yang ada. Prosedur dalam proses penganggaran keuangan Desa berdasarkan Permendagri No. 113 tahun 2014 adalah mulai dari perencanaan, pelaksanaan, penatausahaan, pelaporan dan petanggungjawaban dengan periode 1 (satu) tahun anggaran yang terhitung mulai tanggal 1 januari hingga 31 Desember.

Pada tahap awal yakni perencanaan, dilakukan dengan musyawarah yang tentunya melibatkan BPD (Badan Permusyawaratan Desa), lembaga Desa, terutama masyarakat Desa. Seperti temuan peneliti pada point transparan dan partisipatif bahwa pada tahap perencanaan dalam pengelolaan keuangan Desa, pemerintah Desa selalu melakukan rapat musyawarah. Rapat musyawarah tersebut juga melibatkan BPD (Badan Permusyawaratan Desa), lembaga Desa, serta tokoh masyarakat. Hal ini dapat dibuktikan dengan adanya daftar hadir serta dokumentasi dalam setiap rapat yang diadakan oleh Desa. Pada tahap perencanaan ini, pemerintah Desa mengadakan rapat Musdus (Musyawarah Dusun), Musdes (Musyawarah Desa), kemudian Musrenbangdes (Musyawarah Rencana Pembangunan Desa). Pada tahap ini dilakukan dari tingkat bawah agar tercapai kesejahteraan dengan tepat sasaran.

Pada tahap pelaksanaan, berdasarkan Permendagri No. 113 tahun 2014 menyebutkan bahwa semua penerimaan dan pengeluaran Desa dalam rangka pelaksanaan kewenangan Desa dilaksanakan melalui rekening kas Desa. Dalam Nugroho (2021: 13-14) Rekening Kas Desa (RKD) adalah rekening tempat menyimpan uang pemerintahan Desa yang menampung seluruh penerimaan Desa dan untuk membayar seluruh pengeluaran Desa pada bank yang ditetapkan. Selain itu pelaksana 
Yunita Dewi Rahmawati, Ratna Dewi, Ainun Mardiah I Pengelolaan Dana Desa untuk Pemberdayaan Masyarakat Desa Mulya Subur Kecamatan Pangkalan Lesung Kabupaten Pelalawan

kegiatan bertanggungjawab terhadap tindakan pengeluaran yang menyebabkan atas beban anggaran belanja kegiatan dengan mempergunakan buku pembantu kas kegiatan sebagai pertanggungjawaban pelaksanaan kegiatan di Desa. Pada tahap ini, Desa Mulya Subur memiliki Rekening Kas Desa sendiri sebagaimana yang diungkapkan Kaur Keuangan sebagai berikut: "Pelaksanaannya itu biasanya kan kita dana itu dah cair dari kabupaten terus udah masuk ke rekening Desa". (Wawancara, 06 Mei 2021).

Kemudian dalam pelaksanaanya, setiap orang atau tim yang ditugaskan sebagai pelaksana kegiatan bertanggungjawab terhadap pengeluaran anggaran kegiatan dengan menggunakan buku kas pembantu kegiatan. Buku kas pembantu kegiatan tersebut juga sudah ada dalam system aplikasi keuangan Desa.

Pada tahap penatausahaan, berdasarkan peraturan dilakukan oleh Bendahara Desa. Bendahara wajib mencatat setiap penerimaan dan pengeluaran menggunakan buku kas umum, buku kas pembantu pajak, dan buku bank. Pada penatausahaan pengelolaan keuangan Desa terutama Dana Desa (DD) untuk pemberdayaan masyarakat di Desa Mulya Subur dilakukan oleh Kaur Keuangan sebagai bendahara Desa. Dalam pencatatan penerimaan dan pengeluaran keuangan Desa Kaur Keuangan sudah dibantu menggunakan SISKEUDES (Sistem Keuangan Desa) . Sistem aplikasi keuangan Desa ini, memudahkan Kaur Keuangan dalam menatausahakan seluruh pemasukan maupun pengeluaran keuangan Desa. Pada aplikasi ini tidak hanya membantu Kaur Keuangan dalam penatausahaan, namun dalam pembuatan laporan pertanggungjawaban juga menggunakan aplikasi SISKEUDES.

Berikut adalah dokumentasi buku kas umum, buku kas pembantu pajak, dan buku bank yang ada dalam system aplikasi keuangan Desa di Desa Mulya Subur.

Pada tahap pelaporan dan pertanggungjawaban, berdasarkan Permendagri No. 113 tahun 2014 laporan realisasi pelaksanaan APBDesa disampaikan kepada Bupati/Walikota oleh Kepala Desa melalui Camat. Laporan realisasi tersebut berupa laporan smester pertama dan laporan smester akhir tahun. Desa Mulya Subur sendiri pada pelaporan sudah melakukannya sesuai dengan peraturan, yang mana format laporan presmester tersebut sesuai dengan yang sudah diatur dalam Permendagri. Selain itu penyelesaian laporan ini pun dilakukan dalam aplikasi SISKEUDES sehingga lebih mudah.

Selain itu pemerintah Desa juga mempunyai tanggungjawab berupa laporan pertanggungjawaban realisasi pelaksanaan APBDes setiap akhir tahun anggaran. Laporan ini berupa laporan dari keseluruhan pengelolaan keuangan Desa termasuk Dana Desa (DD) untuk pemberdayaan masyarakat selama 1 (satu) tahun anggaran. Desa Mulya Subur pada tahap pertanggungjawaban ini sudah dilakukan sesuai dengan peraturan yang berlaku, yang mana format dari laporan pertanggungjawaban pun sudah ada dalam system aplikasi SISKEUDES.

Tidak hanya itu, dalam Permendagri No. 113 tahun 2014 juga disebutkan bahwa laporan pertanggungjawaban disampaikan paling lambat 1 (satu) bulan setelah akhir tahun anggaran berkenaan, artinya batas akhir pelaporan pertanggungjawaban tersebut adalah pada bulan Januari akhir. Di Desa Mulya Subur sendiri, waktu pelaporan pertanggungjawaban dilakukan dengan tepat waktu sebagaimana yang telah peneliti jelaskan pada point asas akuntabel sebelumnya. Pada akhir tahun, yakni pertanggal 31 Desember pemerintah Desa sudah melakukan tutup buku, sehingga tidak ada keterlambatan dalam pelaporannya.

Dengan demikian dapat diketahui bahwa dalam penerapan asas tertib dan disiplin anggaran di Desa Mulya Subur sudah dilakukan dengan baik. Dalam pengelolaa Dana Desa (DD) di Desa Mulya Subur sudah dilakukan sesuai dengan prosedur mulai dari perencanaan, pelaksanaan, penatausahaan, hingga pelaporan dan pertanggungjawaban. Dalam menjalankan prosedur tersebut pun dilakukan berdasarkan aturan yang berlaku. Selain itu, anggaran Dana Desa (DD) di Desa Mulya Subur dikelola dengan tepat waktu, yaitu dalam periode 1 (satu) tahun anggaran dimulai dari tanggal 1 Januari hingga 31 Desember.

Faktor penghambat dalam pengelolaan Dana Desa (DD) untuk pemberdayaan masyarakat di Desa Mulya Subur Kecamatan Pangkalan Lesung Kabupaten Pelalawan

Disetiap kelebihan pasti ada kekurangan, begitulah istilah yang sering kita dengar. Hal ini pun berlaku dalam pengelolaan Dana Desa untuk pemberdayaan Masyarakat di Desa Mulya Subur. Dalam merealisasikan segala 
sesuatu tidak lepas dari kekurangan yang berupa kendala-kendala yang dihadapi. Pada point ini akan dibahas mengenai factor penghambat dalam pengelolaan Dana Desa (DD) untuk pemberdayaan masyarakat di Desa Mulya Subur Kecamatan Pangkalan Lesung Kabupaten Pelalawan. Adapun factor penghambat pengelolaan Dana Desa (DD) untuk pemberdayaan masyarakat di Desa Mulya Subur berdasarkan hasil penelitian yaitu partisipatif.

Berdasarkan temuan peneliti pada pembahasan sebelumnya bahwa factor penghambat dalam pengelolaan Dana Desa (DD) untuk pemberdayaan masyarakat di Desa Mulya Subur adalah pada penerapan asas partisipatif. Dimana partisipasi dari masyarakat yang cenderung pasif dalam mengikuti musyawarah dalam perencanaan pengelolaan Dana Desa (DD) untuk pemberdayaan masyarakat. Adanya program pemberdayaan masyarakat yang telah terealisasi adalah atas prakarsa dari pemerintah Desa, dan bukan atas dasar usulan dari kebutuhan masyarakatnya sendiri. Selain itu, masyarakat juga tidak berinisiatif untuk mengkritik ataupun mengajukan program yang menjadi kebutuhannya. Masyarakat hanya bersikap menerima saja usulan program pemberdayaan yang akan dijalankan nantinya dari pemerintah Desa.

Oleh sebab kegiatan pemberdayaan yang dijalankan tidak sesuai dengan kebutuhan dari masyarakatnya, maka apa yang menjadi tujuan adanya program tersebut tidak terwujud. Seharusnya ketika merencanakan kegiatan pemberdayaan baik itu berupa pelatihan, terebih dahulu memperhatikan kebutuhan dari masyarakat dengan memberikan ruang seluasluasnya bagi masyarakat untuk mengajukan apa yang menjadi kebutuhannya. Tidak hanya itu, masyarakat pun juga dituntut untuk aktif dalam mengikuti setiap musyawarah dengan menyuarakan apa yang menjadi kebutuhannya dan tidak hanya bersikap menerima saja.

Selain factor yang menghambat pengelolaan Dana Desa tersebut di atas, peneliti juga menemukan kekurangan dalam pengelolaan Dana Desa (DD) di Desa Mulya Subur berdasarkan pembahasan sebelumnya. Adapun kekurangan tersebut adalah dalam memprioritaskan penggunaan Dana Desa (DD) di Desa Mulya Subur masih terfokus pada pembanguna fisik. Hal ini turut diungkapkan oleh Kasi Pelayanan sekaligus Tim Pelaksana
Kegiatan Pemberdayaan, beliau mengatakan: "Porsinya lebih banyak ke pembangunan, alasannya ya karna masih banyak infrastruktur yang belum dibangun dan mendesak untuk dibangun. Seperti perbaikan jalan Desa, jalan akses pertanian, pembangunan gedung serba guna Desa kemudian drainase".

Berdasarkan ungkapan Kasi Pelayanan tersebut bahwa focus penggunaan anggaran Dana Desa (DD) adalah pada pembangunan infrastruktur. Focus penggunaan anggaran tersebut pada pembangunan sebab masih banyak infrastruktur di Desa yang belum di bangun.

Dengan demikian, dapat terjawab mengenai permasalahan kemiskinan yang terus bertambah setiap tahunnya di Desa Mulya Subur, serta rencana pembuatan usaha ekonomi kreatif yang hingga kini belum terwujud. Permasalahan utamanya adalah dalam mengadakan program pemberdayaan masyarakat merupakan prakarsa dari pemerintah Desa dan bukan atas dasar keinginan ataupun kebutuhan dari masyarakat sendiri. Sehingga rencana membangun usaha baik itu kelompok maupun individu dari hasil pelatihan pembuatan keripik buah pun tidak terlaksana. Selain itu partisipasi dari masyarakat yang masih pasif, yaitu bersikap menerima saja apa yang direncanakan dari pemerintah Desa dalam hal ini program pemberdayaan, sehingga kemauan masyarakat untuk mengembangkan hasil dari pelatihan pembuatan keripik buah pun tidak ada. Bahkan mereka merasa kurang percaya diri bila ingin membuka usaha sendiri dengan alasan takut jika tidak mendapat keuntungan. Selain itu juga dalam pengelolaan Dana Desa (DD) di Desa Mulya Subur masih terfokus pada pembangunan fisik.

\section{PENUTUP}

Dalam Pengelolaan Dana Desa (DD) untuk pemberdayaan masyarakat di Desa Mulya Subur Kecamatan Pangkalan Lesung Kabupaten Pelalawan, penerapan asas transparan sudah dilakukan dengan baik. Pemerintah Desa sudah menerapkan transparansi mulai dari proses perencanaan hingga pelaporan dan pertanggungjawaban kepada masyarakat. Selain itu masyarakat dapat mudah mengakses informasi pengelolaan Dana Desa (DD) melalui baliho yang dipasang. Pada penerapan asas akuntabel sudah dilakukan dengan baik pula. Pemerintah Desa mempertanggungjawabkan pengelolaan 
Yunita Dewi Rahmawati, Ratna Dewi, Ainun Mardiah| Pengelolaan Dana Desa untuk Pemberdayaan Masyarakat Desa Mulya Subur Kecamatan Pangkalan Lesung Kabupaten Pelalawan

keuangan Desa terutama Dana Desa (DD) untuk pemberdayaan masyarakat dengan membuat laporan pertanggungjawaban sesuai aturan yang berlaku. Pada penerapan asas partisipatif belum berjalan dengan maksimal, sebab pemerintah Desa belum memberikan ruang bagi peran serta masyarakat dengan baik. Selain itu masyarakat Desa Mulya Subur masih bersikap pasif dalam berpartisipasi. Selain itu pada penerapan asas tertib dan disiplin anggaran telah dilakukan dengan baik. Pemerintah Desa telah mengikuti prosedur dan aturan yang berlaku dalam pengelolaan Dana Desa (DD). Penggunaan anggaran Dana Desa (DD) juga dilakukan dalam 1 (satu) periode saja sesuai dengan peraturan. Dengan demikian berdasarkan hasil analisis peneliti bahwa penerapan keseluruhan asas-asas pengelolaan Dana Desa (DD) di Desa Mulya Subur masih kurang maksimal.

Factor penghambat dalam pengelolaan Dana Desa (DD) untuk pemberdayaan masyarakat di Desa Mulya Subur yakni dalam penerapan asas partisipatif. Pemerintah masih kurang maksimal dalam memberikan ruang bagi peran serta masyarakat untuk berpartisipasi. Program pemberdayaan masyarakat merupakan usulan dari pemerintah Desa sendiri (Top-Down), bukan dari masyarakat sendiri (Buttom-Up). Di sisi lain partisipasi dari masyarakat Desa cenderung bersikap pasif, masyarakat bersikap menerima saja apa yang diberikan pemerintah dalam hal ini pemberdayaan masyarakat tanpa mengkritik ataupun memberi usulan sesuai kebutuhannya sendiri. Selain itu, dalam pengelolaan Dana Desa (DD) di Desa Mulya Subur masih cenderung terfokus pada pembangunan fisik.

\section{DAFTAR PUSTAKA}

Arif Sifianto. 2017. Kontribusi Dana Desa Terhadap Pembangunan Dan Pemberdayaan Masyarakat Di Kebumen Dan Pekalongan. Jurnal: Inovasi Kebijakan. Vol. 1, No. 1.

Boedijono, dkk. 2019. Efektivitas Penglolaan Dana Desa Untuk Pembangunan Dan Pemberdayaan Masyarakat Desa Di Kabupaten Bondowoso. Jurnal: Riset Manajemen Dan Bisnis. Vol. 4, No. 1

Chasanah, Khuswatun, Slamet Rosyadi, dan Denok Kurniasih. 2017. Implementasi Kebijakan Dana Desa. Jurnal: The
Indonesian Journal of Public

Administration. Vol. 3, No. 2.

Damsar dan Indrayani. 2016. Pengantar Sosiologi Perdesaan. Jakarta: Kencana.

Deputi Bidang Pengawasan Penyelenggaraan Keuangan Daerah 2015. 2015. Petunjuk Pelaksanaan Bimbingan \& Konsultasi Pengelolaan Keuangan Desa. Jakarta: Badan Pengawasan Keuangan Dan Pembangunan.

Dewi, Revina Kumala. 2020. Pemanfaatan Dana Desa Dalam Pembangunan Desa Seremban Jaya Kecamatan Rimba Melintang Kabupaten Rokan Hilir Tahun 2018. Skripsi. Pekanbaru: UIN SUSKA Riau.

Handono, Setiyo Yuli, Kliwon Hidayat, dan Mangku Purnomo. 2020. Pemberdayaan Masyarakat Pertanian. Malang: Universitas Brawijaya Press.

Kementrian Keuangan Republik Indonesia. 2017. Buku Pintar Dana Desa. Dana desa untuk kesejahteraan rakyat. Jakarta: Direktorat Jenderal Perimbangan Keuangan.

Liputan6.com.2021.Jumlah penduduk Indonesia di 2020 capai 271.349 .889 juta jiwa.

https://m.liputan6.com/bisnis/read/4463

388/jumlah-penduduk-indonesia-di-

2020-capai-271349889-juta-jiwa.

(Diakses pada 23 Maret 2021 pukul 23:11 WIB).

Maryani, Dedeh, dan Ruth Roselin E. Nainggolan. 2019. Pemberdayaan Masyarakat. Yogyakarta: Deepublish.

Mela Arnani.2021.Angka Kemiskinan Indonesia Naik, Ini Data Per Provinsi. https://www.kompas.com/tren/image/20 21/02/18/110300865/angka-kemiskinanindonesia-naik-ini-data-perprovinsi?page $=1$ (Diakses pada 23 Maret 2021 pukul 22:53 WIB).

Munthe, Risma N, dkk. 2021. Sistem Perekonomian Indonesia. Medan: Yayasan Kita Menulis. 
Yunita Dewi Rahmawati, Ratna Dewi, Ainun Mardiah| Pengelolaan Dana Desa untuk Pemberdayaan Masyarakat Desa Mulya Subur Kecamatan Pangkalan Lesung Kabupaten Pelalawan

Murdiyanto, Eko. 2020. Metode Penelitian Kualitatif. Yogyakarta: LP2M UPN "Veteran" Yogyakarta Press.

Nain, Umar. 2019. Pembangunan Desa Dalam Perspektif Sosiohistoris. Makassar: Garis Khatulistiwa.

Nugroho, Riant, dan Firre An Suprapto. 2021. Manajemen Keuangan Desa Bagian 3: Pelaksanaan Keuangan Desa. Jakarta: Elex Media Komputindo.

Nugroho, Riant, dan Firre An Suprapto. 2021. Manajemen Keuangan Desa Bagian 2: Perencanaan Keuangan Desa. Jakarta: Elex Media Komputindo.

Peraturan Menteri Dalam Negeri Republik Indonesia Nomor 113 Tahun 2014 Tentang Pengelolaan Keuangan Desa.

Peraturan Menteri Dalam Negeri Republik Indonesia Nomor 114 Tahun 2014 tentang Pedoman Pembangunan Desa.

Peraturan Menteri Desa, Pembangunan Daerah Tertinggal, Dan Transmigrasi Republik Indonesia Nomor 16 Tahun 2018 Tentang Prioritas Penggunaan Dana Desa Tahun 2019.

Peraturan Pemerintah Nomor 60 Tahun 2014 Tentang Dana Desa.
Perbantara, Arif, dan Mujianto. 2019. Modul Pemberdayaan Masyarakat Desa. Jakarta: Kementerian Desa, Pembangunan Daerah Tertinggal Dan Transmigrasi.

Siagian, Valentine, dkk. 2020. Ekonomi dan bisnis Indonesia. Medan: Yayasan Kita Menulis.

Sumarto, Rusman Hadi. 2019. Pemanfaatan Dana Desa Untuk Peningkatan Taraf Hidup Masyarakat Pedesaan Melalui Pemberdayaan Masyarakat Desa. Jurnal: Publicuho. Vol. 2, No. 2.

Tahir, Arifin. 2014. Kebijakan Publik \& Transparansi Penyelenggaraan Pemerintah Daerah. Bandung: Alfabeta.

Tim Visi Yustisia. 2016. Pedoman Resmi Petunjuk Pelaksanaan Dana Desa. Jakarta: Visimedia.

Undang-Undang Nomor 32 Tahun 2004 Tentang Pemerintahan Daerah.

Undang-Undang Republik Indonesia Nomor 6 Tahun 2014 Tentang Desa.

Warjio. 2016. Politik Pembangunan: Paradoks, Teori, Aktor, dan Ideologi. Jakarta: Kencana. 